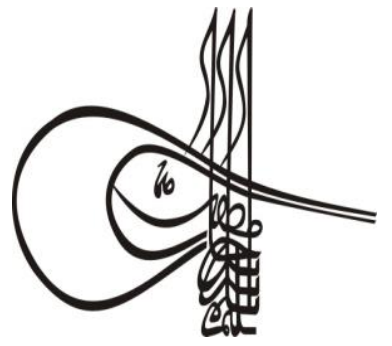

Received/Geliş: 04.02.2019

\section{Turkísh Studíes}

Volume 14 Issue 3, 2019, p. 1371-1390

DOI: 10.29228/TurkishStudies. 22715

ISSN: $1308-2140$

Skopje/MACEDONIA-Ankara/TURKEY

Research Article / Araştırma Makalesi

Article Info/Makale Bilgisi

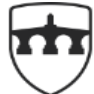

INTERNATIONAL BALKAN UNIVERSITY

EXCELLENCE FOR THE FUTUR IBU.EDU.MK

$\checkmark$ Accepted/Kabul: 10.06 .2019

Go Report Dates/Rapor Tarihleri: Referee 1 (03.03.2019)-Referee 2 (04.03.2019)-Referee 3 (19.02.2019)- Referee 4 (26.03.2019)

This article was checked by iThenticate.

\title{
AVRUPA'DA GÖÇ, YOKSULLUK, DIŞLANMA VE İSLÂMî FEMINIZM
}

\author{
Şirin DILLI' - Laura NAVARRO GARCIA**
}

\section{öz}

Seksenli yıllarda tarihsel feminist hareket Avrupa'daki birçok ülkede güçlenmekteyken, 'yeni' akımlar hegemonyacı feminist teoriyi ve uygulamayı yeniden tanımlamaya başlar. 'Üçüncü Dalga Feminizm', 'Sömürgecilik Sonrası Feminizm' veya 'Post-Modern Feminizm' gibi terimlerle gruplandırılan bu yeni akımlar, ortak bir kaygıyı paylaşır: Göç, yoksulluk ve dışlanma sorunsallarından yola çıkarak Batılı, beyaz, laik ve orta sınıf kadınların mücadeleleri üzerine yoğunlaşan hegemonyacı feminizmin etno-merkezci ve sınıfçı vizyonlarının sorgulanması (Köroğlu, 2013; Doria, 2011; Rhouni, 2009, Andujar, 2014; Mir Husseini, 2010).

'Üçüncü Dalga Feminizm', ‘Sömürgecilik Sonrası Feminizm' veya 'Post-Modern Feminizm' içerisinde yer alan İslami Feminizm, eşitlik ve adalet temelli şu soruları sorar: Irkçılık ve sınıf kavramları toplumsal eşitlik ve adalet deneyimlerinin oluşumunu nasıl etkilemektedir? Bir dini tatbik etmek, kadın haklarını savunmaya engel midir? Göçmen ve yoksul Müslüman kadınların gündelik hayata dair dertleri, sözüm ona 'evrensel' bir feminizm modelinin içinde neden yer al-a-mamıştır?

Biz çalışmamızda, ‘İslami Feminizm’in tarihsel ortaya çıkış sürecini ele aldıktan sonra, son on yıllık süreç içerisinde Avrupa'da öne çıkan en önemli Müslüman Feminist düşünürlerin göç, yoksulluk ve ötekileştirme bağlamında Feminist kuramlara getirdikleri yeni sorunsalları ve bunların sonucunda 'Üçüncü Dalga Feminizm', 'Sömürgecilik Sonrası Feminizm' veya 'Post-Modern Feminizm' içerisinde ortaya çıkan güncel akademik tartışmaları paylaşacağız.

Doç. Dr., Giresun Üniversitesi, E-posta: sirin.dilli@giresun.edu.tr

Dr., Valencia Üniversitesi, E-posta: launagar@yahoo.es 
Araştırmamız, Avrupa'daki mevcut sosyal ve akademik tartışmalar içerisindeki öncelikli iki konuyu birlikte düşünmeyi önermekte: Toplumsal Cinsiyete Dayalı Ayrumcilık ve Yoksulluk.

Valladolid Üniversitesi Sosyoloji Bölümü tarafindan kabul edilen ve 2018 Temmuz-Eylül ayları arasında Giresun Üniversitesi'nin desteği ile araştırma izni kullanılarak İspanya'da ve Fransa'da yürütülen çalışma; toplumsal cinsiyete dayalı ayrımcılık konusunu gündeme getirirken, tarihsel olarak Avrupa merkezli hegemonyac1 feminist teorilerin bertaraf ettiği dini unsuru esas alan 'İslâmî feminizm' üzerinden mültecilik, yoksulluk ve dışlanma sorunsalını ele almıştır.

Anahtar Kelimeler: Avrupa, Yoksulluk, İslam, Feminizm, Kesişimsellik

\title{
MIGRATION, POVERTY \& ISLAMIC FEMINISM IN EUROPE
}

\begin{abstract}
In the eighties, while historical feminist movement is strengthening in many countries over Europe, 'new' currents starts to (re)define the hegemonic feminist theory and practice. These new movements, grouped with terms such as 'Third Wave Feminism', 'PostColonial Feminism' or 'Post-Modern Feminism', share a common concern: Questioning the ethno-centrist and classist visions of hegemonic feminism, focusing mainly on Western, white, laic and middle class women's concerns (Doria, 2011; Rhouni, 2009, Andujar, 2014; Mir Husseini, 2010).

As part of the 'Third Wave Feminism', 'Post-colonial Feminism' or 'Post-Modern Feminism' movements, Islamic Feminism rises the following questions on equality and justice: How do the concepts of racism and class affect the formation of social experiences on social equality and justice? Should a religious practice be an obstacle for advocating women's rights? Why aren't everyday life worries of immigrant and/or poor Muslim women included into a so-called 'universal' model of feminism?

This paper gives a snapshot on two of the most relevant social and academic debates that arise nowadays. On the one hand, the debate dealing with feminism and religions, developed especially within the framework of current Gender Studies and feminist activism. On the other hand, the debate related to the causes and consequences of poverty and social injustice -rather framed in Poverty Studies- and, particularly, the role of women in the eradication of different social inequalities. We will deepen these discussions through the study of the 'Islamic feminism', analyzing the characteristics shared by different Islamic feminist theories and movements, highlighting the most important Islamic feminist thinkers and activists who contributed to the debate on reducing poverty and social injustice in recent decades.

The study, suported by the Departments of Sociology at the University of Valladolid and Giresun University, is based on a general state of art completed between July-September 2018 in France and Spain, with the idea to analyse the issues of migration, poverty and
\end{abstract}


exclusion over gender-based discrimination within an Islamic feminist prespetive -a perspective historically neglected for its religious aspect by the European-based hegemonic feminist theories-.

\section{STRUCTURED ABSTRACT}

Starting 1980s, many European countries witness the rise of Western feminist movements (Nash, 2004). On the other hand, new feminist currents began to redefine the hegemonic feminist theory and put its applications into discussion (Badran, 2010).

Black feminism and post-colonial feminism from the USA nourish these new currents rising within European feminist activists who minds about taking into account demands rising of under-represented women, living at the margins of the European society (Benelly et al., 2006; Nash et al., 2013).

Their idea is to elaborate a feminist model wide enough to take into account subaltern voice(s), while speaking on 'behalf of' all women. Their idea is to take into consideration demands rising from 'under-' and/or 'mis-' represented women staying at the periphery of the Western, secular, white, middle class system of values (Mohanty, Russo \& Torres, 1991).

To speak in a rough dichotomic way, these alternative feminist currents rising from within Europe and the US are a quest for the 'West' to face its own colonial past and share a common demand, wide enough to embrace all women living in contemporary European societies, no matter their class, race and religion (Ibid.). To be representative of the rising alternative feminist movements coming from the margins, debates take shape at the crossroads of the 'third wave feminism', 'post-colonial feminism' and 'post-modern feminism'. A particular feminist group at the crossroads are surely Muslim women.

Via Islamic feminism, Muslim women activists demand to question the ethnocentric and classist vision not only of the West, but also of the Western based hegemonic feminism (Marable\&Aidi, 2009; Suzack, 2010). This movement takes its place within the post-modern and post-colonial feminist movements as a reaction to the marginalisation of 'some' citizens who live across Europe and the US, because being descendants of first generation immigrants.

Subsequent to Western hegemonic feminism, Islamic feminism situates itself within the post-colonial feminist movements coming from the margins. For Muslim feminists, their own presence in the European ground is a result of the dark colonial past (Ali, 2012).

Islamic feminism primarily believes that feminism should manage to embrace all women. Therefore, Islamic feminism tackles first the issue of violence and discrimination of 'the' white women over the 'other' women (Martín Muñoz, 2005). By criticising Europe based hegemonic feminism as a movement that do not manage to uphold profits of women's seen as second class because of their religion, ethnic background and class; Islamic Feminism strengthens its raison d'être and search for legality within the European Feminist public sphere. It considers poverty and class discrimination as a natural part/extension of gender-based social inequality. 
As such, Islamic feminism emphasizes not only the differences and inequalities between men and women, but also the race, religion, social class differences between women themselves -as a sexual minority, a migrant, a refugee, a Muslim and/or a poor women- and inequalities originating from these differences (Idem). For this reason, Muslim feminists speak about 'women' instead of 'woman' and 'unfairness' instead of 'inequality'. But why to claim for the concept of 'unfairness' instead of 'inequality' between men and women and/or the white and the other?

Muslim feminists suggest a feminist ideal and map of actions that make room for the needs of the 'oppressed' women, as refugees and migrants in Europe. This feminist ideal involves living in a fairly secular State equal to all religions represented within the European public sphere(s); and urges to have equal participation of women to employment regardless of one's religion (Marcotte, 2010). These claims of Islamic feminism are very much interesting since feminist movements are known for their distance with religion.

Although Islamic feminism arises late, it also attends to interrogate as all feminist movements, inequalities and differences between men and women in Western Europe. At this point, interesting is the correlation between feminism and religion that this approach finds. For European Muslim feminists, if access to the job stays an issue for most Muslims, its impact is much heavier for Muslim women.

By following the tension(s) and discussion(s) between European Muslim Feminists and the European Hegemonic Feminist debate, as a researcher, our attempt would be to contribute to the European Feminist Thought. The idea would be to gather their own conversation together with the concept of 'border' in social sciences (Yamani\&Allen, 1996). 'Border' as a sociological concept is an important category in which it is possible to study the situation of marginalised women, frustrated by the lack of representation within the European Feminist Thought. Yet, by doing so, the challenge for European Muslim Women would be to not be trapped at their turn by the 'Othering' discourse towards the 'White' woman.

Keywords: Europe, Poverty, Islam, Feminism, Intersectionality.

"Biliyorum, çoğu zaman, hem de hemen her yerde, haksızlık egemendir. Doğal gibi, doğruluk gibi, haklılık gibi göründüğü de çok olur. 'Bu böyledir, böyle gelmiş, böyle gider: yapılacak hiçbir şey yok!' der insanlar. Sonra bir yerlerden bir dip dalgası gelir, önünde ne varsa yerle bir etmeye başlar, adaletin ucu görünür, insanlar 'Bu böyle süremez' derler ve bu böyle sürmez artık." (Tahsin Yücel, Gökdelen, s. 255).

\section{Giriş}

Araştırmamız, Avrupa'daki mevcut sosyal ve akademik tartışmalar içerisindeki öncelikli iki konuyu birlikte düşünmeyi önermektedir: Toplumsal Cinsiyete Dayalı Ayrımcılık ve Yoksulluk.

Araştırmacılar; toplumsal cinsiyete dayalı ayrımcılık konusunu gündeme getirirken, tarihsel olarak Avrupa merkezli hegemonyacı feminist teorilerin bertaraf ettiği dini unsuru esas alan 'İslâmî 
feminizm' üzerinden göç, yoksulluk ve dışlanma sorunsalını ele alacaklardır. Öncelikle çalışmamız, Avrupalı Müslüman kadınların kendi taleplerini Batılı, beyaz, laik ve orta sınıf kadınların kaygı ve ilgileri ile nasıl ilişkilendirdiği üzerinde yoğunlaşacak; Avrupalı feministlerle girmiş oldukları bu diyalog ve dolayısıyla meşruiyet arama sürecinde Müslüman kadınların hegemonyacı, etnomerkezci ve sınıfçı hegemonik feminizmin vizyonunu ne oranda sorgulamaya ittiğini de ortaya koyacaktır.

Makalemiz; seksenli yıllarda taleplerini ifade etmeye başlayan Müslüman feministlerin Avrupa'da nasıl yer edindiğini inceleyecek, Avrupa'da farklı İslâmî feminist hareketler tarafından paylaşılan karakteristikler ve ortak amaçlarının yanı sıra kendi çalışma alanlarının derinliğine inecektir ${ }^{1}$.

\section{Hegemonik Feminizm, İslam ve Etno-merkezcilik}

Batı merkezli tarihsel feminist hareket; seksenli yıllarda İspanya gibi birçok Avrupa ülkesinde güçlenirken (Andújar, 2014; Nash, 2004), Fransa gibi diğer Avrupa ülkelerindeki yeni feminist akımlar hegemonyacı feminist teoriyi ve uygulamayı yeniden tanımlamaya başlar ve tartışmaya açar (Badran, 2010).

ABD'den ithal edilen siyahî feminizm ve post-kolonyal feminizm (Benelly et al., 2006; Nash et al., 2013); Avrupa toplumunda ezilmişlerin, yoksulların, dışlanmışların taleplerini dikkate alarak, çevreden/marjlardan gelen ve yükselen alternatif feminist akımları temsil eden bir oluşum şeklinde karşımıza çıkar. Söz konusu akımlar; 'üçüncü dalga feminizm', 'sömürgecilik sonrası feminizm' ve 'post-modern feminizm' başlığı altında şekil alır.

Avrupa'nın ve Amerika'nın kendi içerisinden yükselen, Batı'nın sömürgeci geçmişi ile de yüzleşmesini talep eden bu alternatif feminist hareketler, ortak bir talebi paylaşır: 'Öteki', 'azınlık', 'göçmen', 'Müslüman' ve/veya 'yoksul' kadınlardan gelen taleplerin; Batılı, beyaz, laik ve orta sınıf merkezli değerler sisteminden azade olarak dikkate alınması (Mohanty, Russo \& Torres, 1991).

İslâmî feminizm de; Batı merkezli hegemonyacı feminizmin etnomerkezci ve sınıfçı vizyonunun sorgulanmasını açık açık talep eder. Post-modern veya post-kolonyal feminist hareketler içerisinde yer bulan bu hareket; Batı'nın karanlık sömürgeci geçmişinin neticesi olarak bugün Avrupa'da veya Amerika'da varlık gösteren göçmen kökenli vatandaşların, ötekileştirilerek marjinalleştirilmesine tepki gösterir. Dolayısıyla bahsi geçen feminizm(ler) içerisinde sonradan ortaya çıkmakla birlikte, İslâmî feminizm, 'marjlardan' gelen post-kolonyal feminist akımlar içerisinde yerini alır.

İslâmî feminizm; yoksulluğun, sınıf ayrımcılığının, toplumsal cinsiyet adaletsizliğinin doğal bir parçası olduğu öngörüsüyle, öncellikle 'beyaz' kadının 'öteki' kadına uyguladığı şiddet ve ayrımcılık sorunsalını ele alır (Marable\&Aidi, 2009; Suzack, 2010). Avrupa Merkezli hegemonik feminizme temel eleştirisini 'bir toplumsal hareket olarak kendi içerisinde dini, etnik kökeni ve sınıfi sebebiyle ikinci sınıf muamele gören kadınların çıkarlarını savunan bir hareket ol-a-maması' şeklinde getirir. Varoluş sebebini de bu eleştiri temeli ile sağlamlaştırır ve kamusal alanda meşruiyet kazanır.

Avrupa'nın farklı ülkelerinde yükselen İslâmî feminizm, son on y1llık süre içerisinde özellikle laikçi Devlet anlayışının kalesi Fransa'da önemli tartışmalar açmış, meşru bir zemin bulmuştur.

\section{II. 'Sınır'daki Kadınlar ve Yoksulluk}

İslâmî feminizm yalnızca erkekler ile kadınlar arasındaki farklılıklara ve eşitsizliklere değil, kadınlar arasındaki irk, din ve sosyal sınıfa dayalı farklılıklara ve bu farklılıklardan kaynaklı eşitsizliklere de vurgu yapar. Bu sebeple Müslüman feministler 'kadın' yerine 'kadınlar'dan, 'eşitsizlik' yerine 'adaletsizlik'ten söz eder.

\footnotetext{
${ }^{1}$ Çalışma esnasında desteğini bizlerden esirgemeyen Valladolid Üniversitesi Sosyoloji ve Sosyal Hizmet Bölümü Başkanı Prof. Dr. Miguel VİCENTE MARIÑ̃'ya teşekkürü borç biliriz.
} 
Esas talepleri göz önüne alındığında, Müslüman feministlerin Avrupa'da ezilen Afrikalı kadınların, göçmenlerin ve mültecilerin de ihtiyaçlarını hesaba katan bir düşünce ve eylem çizgisi önerdikleri aşikardır: Her dine kamusal alanda eşit mesafede duran tam anlamıyla laik bir Devlet talebi; ve herkesin istihdam alanına dinî tercihi ne olursa olsun eşit katılım hakkı talebi.

Avrupalı Müslüman feministlerden gelen ve toplumsal cinsiyet adaletsizliğinin doğal bir uzantısı olan emek ve istihdam piyasası ile ilgili bu yeni feminist sorunsalın ifadesi aslında sosyal bilimlerdeki 'sınır' kavramı ile doğrudan anlam bulmaktadır. 'Sınır'; feminist ana akımlar tarafından temsil edildiğini hissetmeyen, marjinal hale getirilmiş, ötekileşmiş olan ve dolayısıyla sınırda kalmış birçok kadının durumunu anlayıp incelemeye izin veren önemli bir kategoridir.

İslâmî feminizm de, 'sınır' kavramı üzerinden kapitalizm ve mevcut globalleşme koşullarını geniş biçimde eleştirir (Dialmy \& Clément, 1997). İslâmî feminizm için hegemonyacı ekonomik model, belli toplumları 'ekonomik gelişmişliğin sınırı'nda bırakarak yeni bir biçimde sömürgeleştirilmesine teşvik etmekte ve bunu yaparken 'sınır'da kalan toplumların ve insanların kültürel, dinî ve sosyal kaynaklarını en iyi ihtimalle 'ötekileştirmeye', en kötü ihtimalle 'silmeye' eğilimlidir.

İslâmî feminizm, yine bu yaklaşım ile Avrupa'yı kasıp kavuran 2008-2010 yılları arasındaki avro krizinin etkileri ile ilgili olarak kalkınmanın ve yoksulluğun önüne geçmek için öncelikle önyargıların ve kafalarda oluşturulan 'sınır'ların yıkılmasının elzem olduğunu gündeme getirir. 'Beyaz olmayan' kadının kenarda tutularak marjinalleştirildiği bir ekonomide, adalet temelli şu soruları sorarak geleneksel feminist akım tartışmalarının ötesine geçer: Irkçılık ve sınıf kavramı, toplumsal adalet deneyimlerinin oluşumunu nasıl etkilemektedir? Bir dini tatbik etmek, kadın haklarını savunmaya engel midir? Göçmen ve yoksul Müslüman kadınların gündelik hayata dair dertleri, iş yaşamına katılım konusunda çektikleri zorluklar, sözüm ona 'evrensel' bir feminizm modelinin içinde neden yer al-a-mamıştır? Yer aldığında ise, neden 'Batılı, beyaz, orta sınıf' kadının değerlendirmesi üzerinden incelenmiştir?

$\mathrm{Bu}$ sorgulamalar, özellikle Edward Said'in Oryantalizm eserinden, Michel Foucault'nun söylem ve güç analizinden, Gayatri Ch. Spivak'ın yapıçözümcü düşüncesinden ve de Homi K. Bhabha'nın sömürgecilik sonrası çalışmalarından etkilenmiştir.

\section{Yoksulluk: Müslüman Kadınlara Sömürge Tarihinden Bir Miras}

Müslüman feministlerin reaksiyonu; sömürgeci gruplar ile sömürgeleştirilmiş 'alt gruplar' arasındaki farklılıkları sağlamlaştırmak adına, Avrupa sömürgeleştirme politikaları tarafından inşa edilen maziye dayalı ırkçı ve cinsiyetçi söylemlere bir tepki niteliğindedir.

Sömürgeleştirilmiş insanların toplumsal cinsiyet ilişkileri, özellikle kadınlar için zalim ve kabul edilemez olarak düşünülürken, sömürge yönetimi ideal aile modelinin nasıl olması gerektiğini dahi tanımlamıştır. Nash ve diğerleri'nin belirttiği gibi (2013), beyaz tenli ve narin kadın, anne ve zevceliğin ideali olarak sunulmuştur. Aslında bu beyaz tenli ve narin kadın idealı, Batı tarafından birçok kez kullanılmıştır. Batı; sömürgeci mazisinde ve Ortadoğu coğrafyasında girmekte olduğu savaşlarda, dikotomik bir mantıkla geri olduğu için sömürgeleştirilmiş ve 'barbar adamların baskısı'na maruz kalan kadınları korumak adına, eşleri tarafından korunan ve toplumsal yaşama katılmasına 'izin' verilen Batılı beyaz kadın modelini siyasi söylemde üst düzeyde tutarak bölgedeki işgallerini veya askeri müdahalelerini meşrulaştırmıştır ${ }^{2}$. Irak ve Afganistan istilaları da dahil olmakla birlikte, 19.yüzyıldan beri bölge kadınlarının haklarına verilen zararlar, ülkelerin istilasını meşrulaştırmak adına önemli bir argüman haline gelmiştir (Said \& Barsamian, 2003). Batı'nın 'sömürgeleştirici

\footnotetext{
2 Afganistan ve Irak Savaşları'nda kadınların durumu, savaşa girmek ve ülke toprağını işgal etmek için meşru zemin hazırlamıştır.
} 
'aydınlık' metropolü ile sömürgelerin 'karanlık' ıssız düzeni söylemi; büyük ölçüde farklı aile modelleri, dolayısıyla kadınlara biçilen rol(ler) üzerinden meşruiyet kazanmıştır.

Kadınları kurtarmak adına yeniden istila edilen topraklar meselesi, Avrupa'daki İslâmî Feminist söylemde devamlı surette eleştirilmekte ve gündemde tutulmaktadır (Martín Muñoz, 2005). 'Vahşi olduğu için sömürgeleştirilmesi meşru bulunan ülke'ye medeniyeti getiren sömürgeci Batı' söyleminin bir söylemden öteye geçmediği, ülkeleri istila edilen kadınların durumundan bizzat görülmektedir. İslâmî feminizm için, yoksulluğa mahkumiyetin kökenlerini de bu 'cici' görünümlü örtük ataerkil söylemde aramak gerkmektedir.

Post-kolonyal dünyadaki ekonomik ve bölgesel gerikalmışlık tartı̧malarında İslâmî feminizmin; iki gerginlik türü üzerinde özellikle durduğunu belirtelim:

- İslâmî feminizmin içerisinde; bir yanda Ortadoğu, Uzakdoğu ve Afrika'da sömürgeci güç rejimlerine karşı kendilerine direnme alanı sağlayan, ama aynı zamanda özellikle muhafazakâr kültürel bir gelenek yapısına ve ataerkil bir aile modeline dayalı idealleştirilmiş bir adaletsiz ataerkil yapıyı meydana getirmeye eğilimli olan hareketlere karşı, İslam'ın özündeki evrensel hümanizmi ve insancıl yaklaşımı inşa etme mücadelesi vardır.

- Diğer yanda ise, feminist hareketler içerisinde, dünyadaki toplumsal cinsiyet adaleti örgütlenmesi için tek geçerli program olarak kendi siyasi gündemini dayatmakta başarılı olmuş hegemonik, Beyaz tenli ve orta sınıf Batılı feminizmle mücadelesi vardır.

Söz konusu post-kolonyal gerilimlerden birinci gerilime önemli katkılar sunmuş olan Fas kökenli İspanyol yazar ve Müslüman feminist Fátima Mernissi (2002); geri kalmışlığa, ve dolayısıyla yoksulluğa mahkum eden sömürgeleştirmeden çok, birleştirici bir söylem olması gereken İslam dinini kendi çıkarı için kullanan ve kendi öz toplumunu istismar eden sömürge dönemi sonrası Devlet anlayışını da eleştirmiştir. Gerçekten de sömürge dönemi sonrası Devlet anlayışı; kadınları, mazlumları, yoksulları bertaraf ederek kapitalizmi benimsemiş, erkek merkezli siyasal hareketlerin içinde Müslümanlığın özündeki hümanist perspektifi bertaraf etmiştir. Bu yönüyle de sömürgeci devletlere benzemiştir.

\section{IV - İslam, Adalet ve İslâmî feminizm-ler}

'İslâmî feminizm'; her toplumsal hareket gibi evrim geçirerek çeşitlenmiş, olgunlaşmış ve dönüşmüş̧ür. Farklı tarihsel bağlamlar ve farklı siyasi konjonktürlerde, farklı İslâmî feminist teoriler ve İslâmî feminist pozisyonlar üretilmiştir. Dolayısıyla aslında İslâmî feminizm yerine, çoğul bir yorumlama ile İslâmî feminizm-ler-den söz etmek yerinde olacaktır.

Tarihsel ve sosyolojik dinamikelerle yoğrulan İslâmî feminizm-ler, her toplumsal hareket gibi sürekli olarak revizyona tâbi tutulmuş, ve kendi içerisindeki tartışmalarla düşün dünyasında yerini almıştır.

\section{Literatürdeki Terminolojik Sorunlar}

Özellikle 11 Eylül saldırıları sonrasında, ekonomik krizdeki bir Avrupa'da, ve 2015 yılındaki Paris Charlie Hebdo ve Kasım saldırılarının devamında Avrupa'da 'İslam' ve 'Müslümanlık' kavramları, terörü çağrıştıran terimler olarak yerini almıştır.

'İslam'ın demokrasi ile uyumluluğu', 'İslam ve Barbarlık', 'İslam ve Adalet' hakkında gündeme getirilen tartışmalar, belirli kalıp cevaplarla sistematik olarak kamuoyunun karşısına çıkmıştır. Bunun için Kasım 2015'teki Paris terör saldırılarının hemen ertesinde Fransa'da karşımıza çıkan farklı siyasî çizgideki çok satan dergi sayılarına bakmak yeterlidir: 


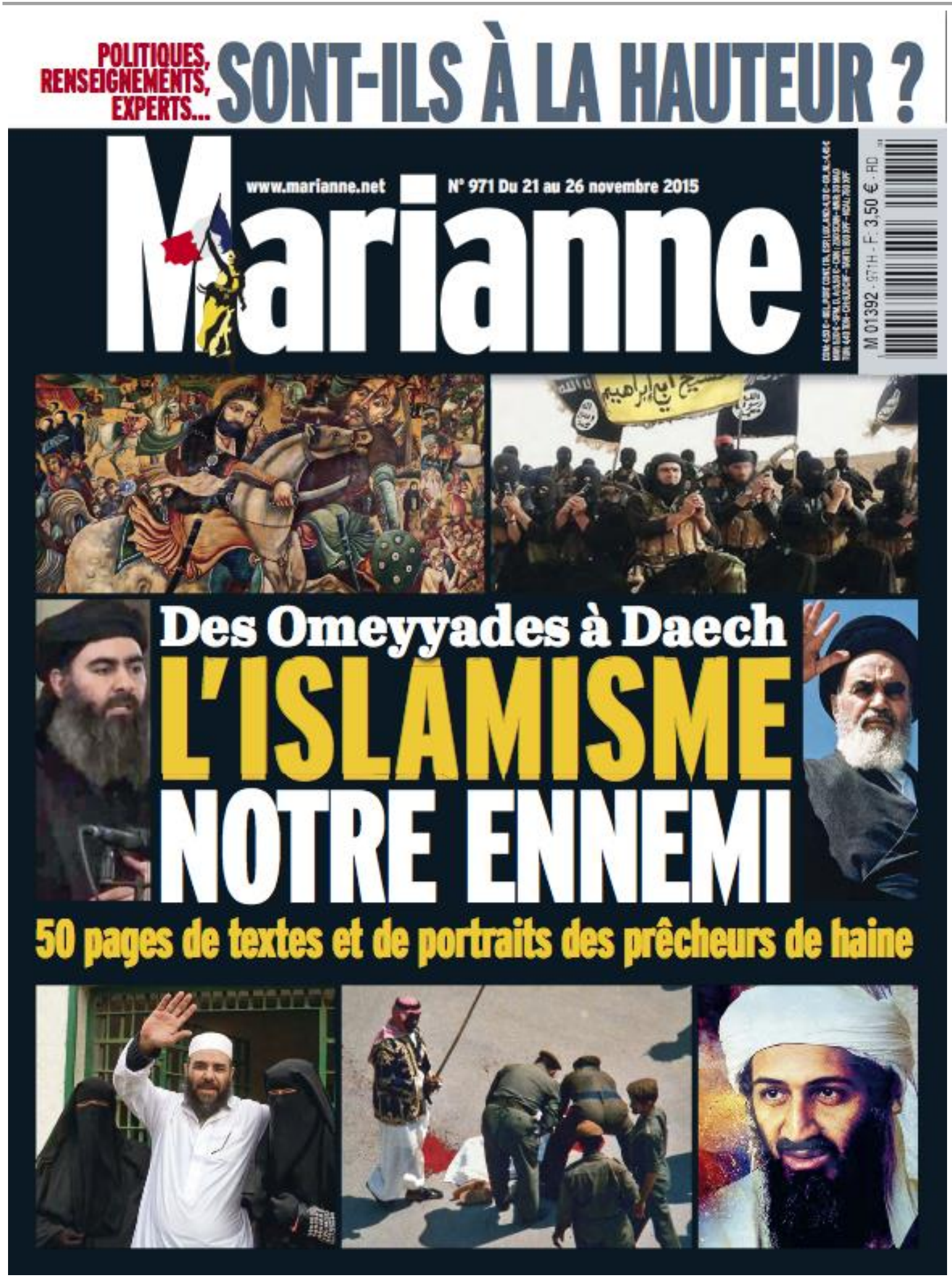

Şekil 1: Sağ görüşlü haftalık siyasî analiz dergisi Marianne'nın Kasım 2015'teki Paris terör saldırılarının hemen ertesinde çıkartmış olduğu 21-26 Kasım tarihli "İslamcılık Düşmanımız (L'Islamisme notre enemi)" sayısı. Görüldüğü üzere görsellerde, yanlızca en uçlardaki bir İslam dini yorumu yansıtılmıştır. 
Üstte görüldüğü üzere, sağ görüşlü haftalık Siyasi Analiz Dergisi Marianne, Paris terör saldırılarının hemen ertesinde, "İslamcılık Düşmanımız (L'Islamisme notre enemi)" sayısını çıkartmış, alt başlı̆̆ını "50 sayfalık metin ve portrelerle nefret saçanların protresi (50 pages de textes et de portraits des pêcheurs de haine)" şeklinde vermiştir. Müslüman Dünyası geri kalmış, yoksul ve kendinden olmayana karşı nefret saçan, adeta terörist ruhlu hastaların kol gezdiği ve kadınların kamusal alanda görünmez olduğu bir diyar olarak gösterilmiştir.

Hristiyan Demokratların tarih dergisi Historia da 'Doğu Dünyası' ile ilgili benzer bir İslam anlayışını yansıtarak, "Atilla'dan İşid'e BARBARLAR Kimdir? (D'Atilla a Daech, qui sont les BARBARES?)" tematik sayısını çıkartmıştır. Bu son derece genellemeci sayı, Paris terör saldırılarının hemen ertesinde yayınlanmıştır: 


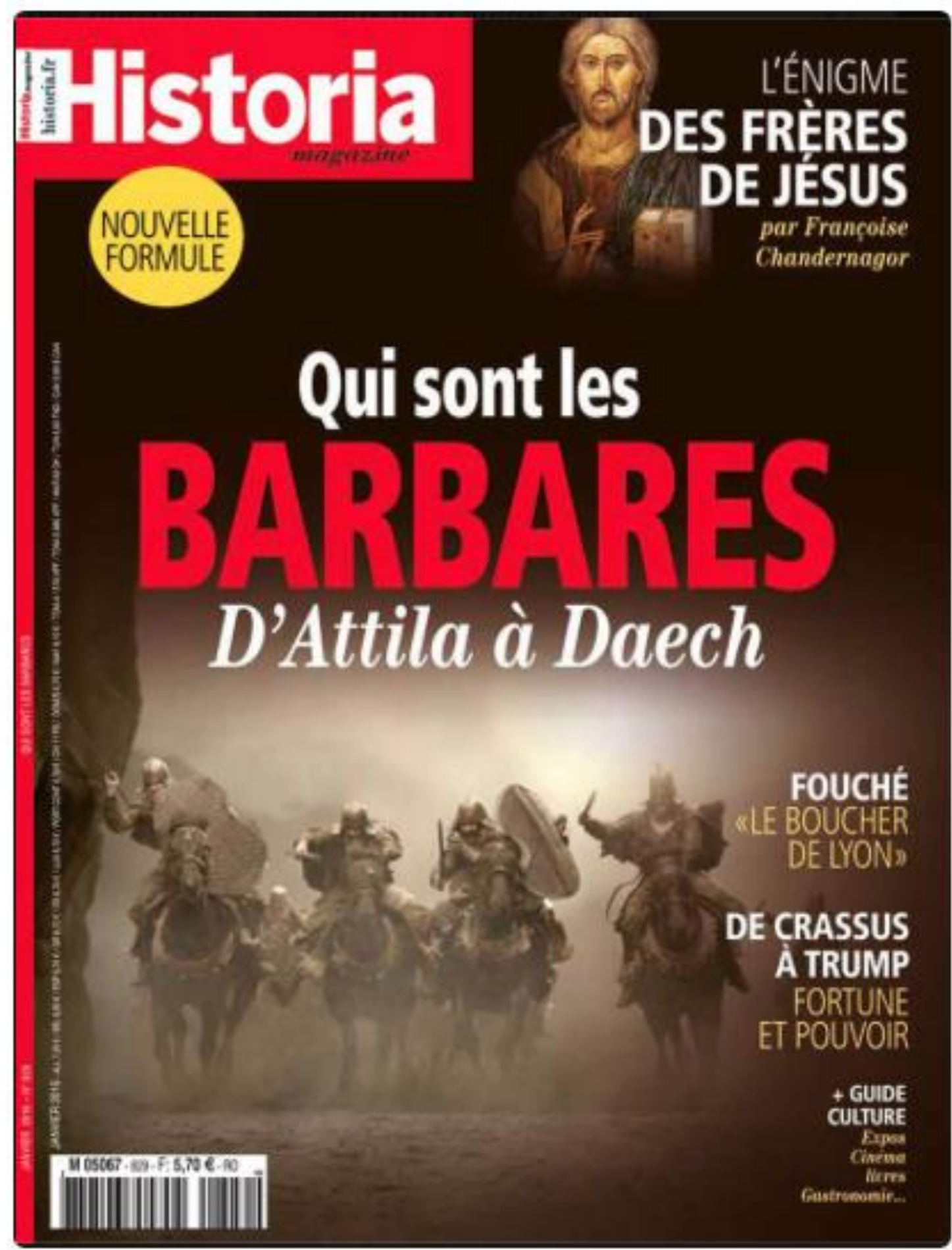

Şekil 2: Aylık siyasî tarih dergisi Historia'nın Kasım 2015'teki Paris terör saldırılarının hemen ertesinde çıkartmış olduğu Aralık 2015 tarihli "Atilla'dan İşid'e Barbarlar Kimdir? (D'Atilla a Daech, qui sont les BARBARES?)" sayısı. Milliyetçi çizgideki dergi kapağının fondaki resminde, savaşçı ve karanlık bir Doğu Dünyası yansıtılmıştır. Dünün 'Büyük Barbar'ı Atilla'nın saldırgan ve puslu geçmişinden sözüm ona tüm Müslümanları temsilen, 'Vahşi Barbar’ İşid çıkagelmiştir. 
Sol görüşlü haftalık mizah dergisi Charlie Hebdo'nun 17 Ocak 2016 tarihli kapak karikatürü ise, kelimenin tam anlamıyla sorunludur. Kapakta yer alan "Göçmenler (Migrants)" başlıklı karikatürde, 2015 yılının Eylül ayında cesedi Bodrum sahiline vuran 3 yaşındaki Suriyeli Aylan Kurdî'nin cesedinin yanında "Küçük Aylan büyüdüğünde ne olurdu? (Que serait devenu le petit Aylan s'il avait grandi?)" diye sorulmaktadır. Ve sorunun yanıtı olarak, kelimesi kelimesine özür dileyerek paylaşalım, "Almanya'da "pandikçi' (Tripotteur de fesse en Allemagne)" cevabı verilmektedir. Büyümüş 'ölü' Aylan, alttaki şekilde görüldüğü üzere, 'domuz suratlı' ve 'pandikçi' profiliyle Alman bir kadını kovalamaktadır:

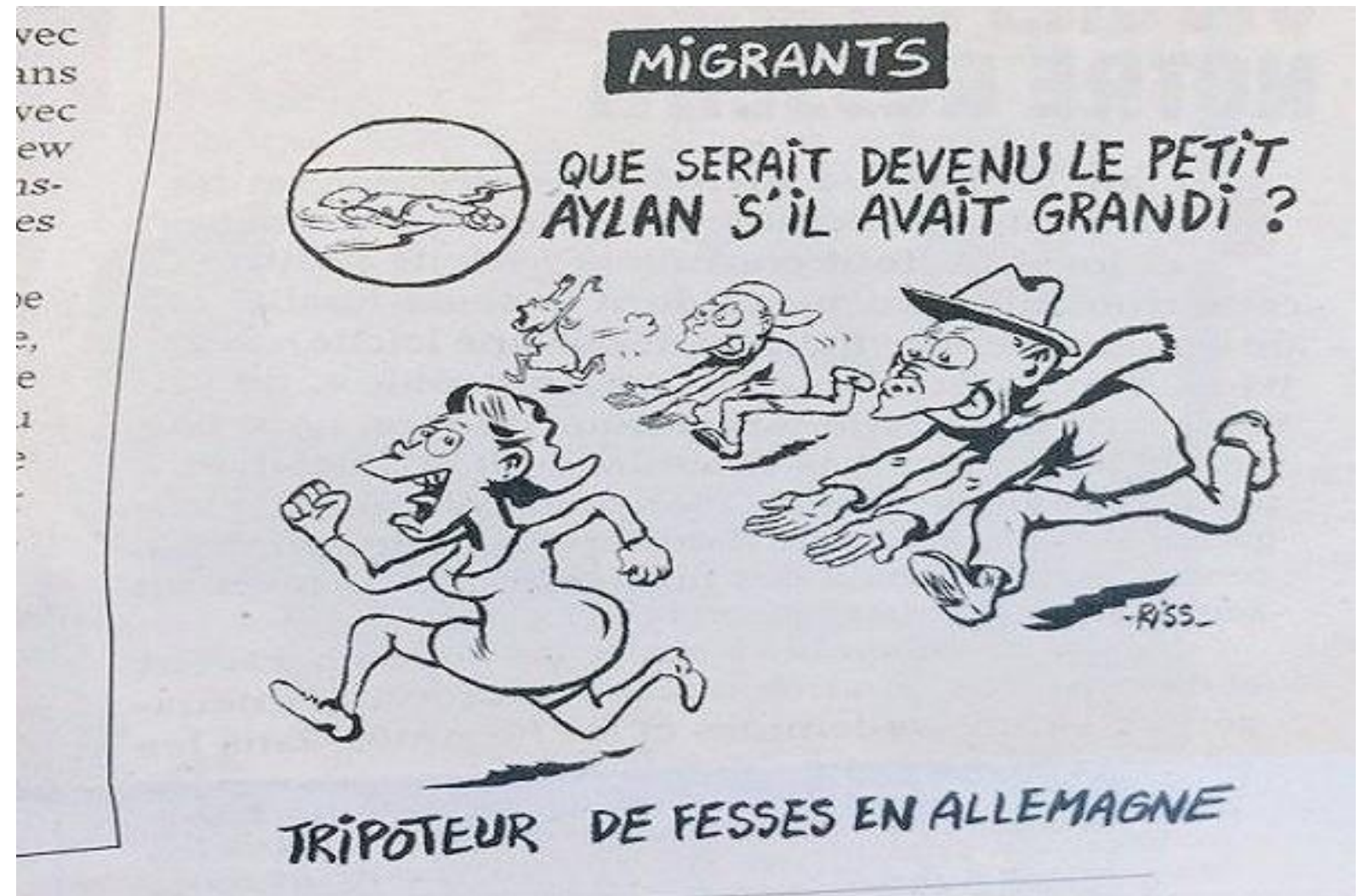

Şekil 3 : Sol görüşlü haftalık siyasî mizah dergisi Charlie Hebdo'nun karikatürcüsü Riss tarafindan çizilen 14 Ocak 2016 tarihli "Küçük Aylan büyüdüğünde ne olurdu? (Que serait devenu le petit Aylan s'il avait grandi?)" isimli karikatür.

$\mathrm{Bu}$ tip söylemleri barındıran haberler, beraberinde toplumsal bir önyargıyı da getirmektedir. Göç alan toplumlardaki bu 'ötekileştirme', 'dışlama' ve 'yoksullaştırma' stratejisi; ne yazık ki adalet, eşitlik ve kardeşlik konusunda Batı'nın da Doğu'ya insanlık öğretecek büyüklükte olmadığını göstermektedir.

Batı Dünyası; yaratmıș olduğu post-kolonyal savaşlardan, yoksulluktan ve kaos ortamından kaçan insanları ülkelerine almamak için, insanlıklarını feda eden söylemler üretme noktasına gelmektedir. Göçmen karşıtlığı yapmak adına, 'ölü çocuk mizah külütürü’nü icat etmek, savaş mağduru bebekleri 'siyasi' malzeme yapmak, aslında bir kimlik çürümesinin (dekadans) de göstergesidir.

Avrupalı Müslümanlar bugün, huzuru bozan potansiyel 'teröristler' olarak, şehir kenarlarına itilmektedir. 'Marjlarda'/'kenar' mahallerlerdeki yaşam ise, iş piyasasına yapılan başvurularda da Müslümanların tercih edilmemesinde sebebiyet vermektedir (Dilli, 2010: 49). Yaşadıkları mahalle, 
taşıdıkları dinî çağrışımlı isim ve dış görüntüleri -sakal veya başörtüsü gibi imgeler-; Avrupalı Müslümanların iş piyasasında belli kalıplara sokulmalarına, ve bu ötekileştirme algısının sonucunda zaman içerisinde yoksullaşmalarına da neden olmaktadır.

Elbette terör saldırılarından doğrudan etkilenmiş olan Fransız halkının acısı büyüktür. 2015 y1lı başında Charlie Hebdo mizah dergisi, İşid'ciler tarafından taranmıştır. Bu saldırılarda dergi; dünyaca ünlü beș politik karikatürcüsünü -Cabu'yü, Charb'i, Tignous'u, Wolinski'yi, Bernard Maris'ikaybetmiştir. Keza Paris'in göbeğinde 13 Kasım 2015 tarihinde meydana gelen terör eylemlerinde 100 'lerce kişi ölmüştür.

Din adına vahşet uygulayan, aklı karanlık, yüreği karanlık, dünyası karanlık katillerin savunulacak yanı yoktur. Ancak din adına, Müslümanlık adına bunu yapanlar yüzünden Avrupa'da sistemin bir parçası olmuş tüm Müslümanların ve Avrupa özelinde göçmen kökenli Müslüman vatandaşların bir anda potansiyel terörist olarak görülmesi de bir o kadar sorunludur.

Ocak 2016'da gündeme gelen ve Müslüman Fransız vatandaşlarını potansiyel terörist varsayan yasa tasarısı ile birlikte, 1930'lar Almanya'sında Nasyonal Sosyalist Alman İşçi Partisi iktidara gelmişcesine, yavaş yavaş 'ulusal güvenlik' adı altında 1 rkçı politikalar bir fiil genişletilmiş; Müslüman toplumu bizzatihi hedef alınmıştır.

Öncelikle, sıkıyönetimin süresi uzatılmıştır. Sonrasında, Fransız Cumhurbaşkanı, 'saf kan' Fransızlara Yılbaşı Seslenişi’nde “"teröre’ bulaşanların çifte vatandaşlıklarının alınacağı"nı açıklamıştır. Fransız Sosyalist Partisi de, Cumhurbaşkanı'nın önceliği doğrultusunda, 2016 yılında ilk olarak bu yasa tasarısını Meclis'ten geçirmeyi hedeflemiştir. Ancak 'saf kan' Fransız Vatandaşlarına bir yılbaşı hediyesi misali sunulan bu yasa tasarısı, sadece çifte vatandaşları ilgilendirdiğinden, tüm 'göçmen kökenli vatandaşlar' bir anda 'ulusal güvenlik' adına, yasa yoluyla, 'potansiyel terörist'e dönüştürülmüştür. Bu da kanımızca, 1930'lar Almanya'sında Nasyonal Sosyalist Parti'nin üstü kapatılmış 'cici' bir uygulaması olarak değerlendirilmelidir.

Evet, Kasım 2015'te Fransa'da 'terör eylemi'ni gerçekleştirenler kendilerini 'Müslüman' olarak tanımlamıştır. Ancak aynı Fransa'da gün olmuştur terör eylemlerini 'Korsikalılar' yapmışlardır; gün olmuştur terör eylemlerini 'anarşistler' gerçekleştirmişlerdir... Hepsi de Fransız vatandaş1 kalmıştır.

İşin acı tarafı, o 'bir grup' eylemciler, bu tip dışlayıcı ve 'ötekileştirici' yasalar gündeme geldikçe; sözde bir İslam adına terör saçarak, belki de başka tepkisel eylemler planlayacaklardır. Ve maalesef bu gruplara zaman içerisinde, 'öteki'leştirilmekten bıkan gençler de katılacaktır...

İşte Müslüman feministler için, İşiD'e katılan ve Devlet'e karşı kin ve nefret besleyen bu gençlerin topluma kazandırılması aciliyet taşımaktadır. En basit öncelikle, bu gençlerin isminin Ahmed, Ali veya Fatma olduğu için dışlanmaması gerekmektedir... 'Öteki'leştirilmiş gençler; taşımış oldukları isim veya siyasî simge olarak algılanan kıyafeteleri sebebiyle hor görülmemeli, toplumun bir kenarına itilerek yoksulluğa itilmemelidir. Çünkü bu gençlerin dışlanması ve mahrumiyet içerisinde yaşamaları, uçlardaki düşüncelere daha kolay meyletmelerine sebebiyet verecektir.

\section{2. İslam, Yoksulluk ve Feminizm Birlikteliği Üzerine Okumalar}

Fransa'daki İslâmî feminist hareketin lideri Saïda Kada (1995) için bireylerin/vatandaşların topluma kazandırılma meselesi; toplum içerisinde herkese -etnik, dini ve sınıfsal kimliği ne olursa olsun- farklılıklarına rağmen eşit firsatların sunulması ve adalet prensibinin gözetilmesinden geçmektedir. Kada için 'göçmen kökenli' olmakla birlikte, Fransız Devleti'nin Müslüman kimlikleri sebebiyle potansiyel terörist muammelesi yaptığı insanları kendi vatandaşı olarak algıla-ya-maması, ciddi bir demokrasi meselesidir (Bouzar \& Kada, 2003). 'Göçmen kökenli' Müslüman vatandaşlar, bu alg1 sebebiyle gündelik hayata katılım konusunda ciddi zorluklar ve adaletsizliklere maruz 
kalmaktadırlar. Söz konusu adaletsizlik, uzun vadede, 'sınır'daki yaşamlara ve yoksulluğa mahkum etmektedir.

Özellikle 11 Eylül sonrasında, İslam dinini tekil ve uç bir okumaya dayanarak 'kriminalize etme' olgusu, Avrupa'da yaşayan Müslüman vatandaşlara karşı yalnızca 1rkçı ve cinsiyetçi yargııarı değil, indirgemeci ve dışlayıcı yaklaşımları da yerleştirmektedir. Genellemeci ve dışlayıcı yaklaşım; İslam, yoksulluk ve feminizm birlikteliğini hareketin merkezine yerleştirmektedir.

İslâmî feminizm-ler, doksanlı yıllarda meşruiyet kazanmaya başlamıștır. Ancak bu, Müslüman kadınların doksanlı yıllardan önce mücadele eden oluşumların veya toplumsal hareketlerin içerisinde yer almadikları anlamına gelmemektedir.

Tarihin gösterdiği gibi, en başta Osmanlı İmparatorluğu'nda yaşayan Müslüman kadınlar (Demir, 2013) ve sonrasında bu hareketlerden etkilenen Arap coğrafyasındaki Müslüman kadınlar (Nash et al., 2013); sömürgeci devletlerin adaletsiz ve insanlıkdışı uygulamalarına karşı ayaklanmalarda önemli roller üstenmişlerdir ${ }^{3}$.

İspanyol düşünür Martín Muñoz'un belirttiği üzere Müslüman kadınlar, İngiliz emperyalizmine karşı gerçekleştirilen 1919'daki sömürge karşıtı Mısır ayaklanmasında önemli rol oynamışlardır (2005). Müslüman kadın dernekleri, Arap Yarımadası'ndaki sömürgeci devletlere karş1 mücadelede aktif rol almakla kalmamış; 1930'lu ve 40’lı yıllarda Arap Müslüman Kadınlar Birliği'ni kurmuşlardır.

Arap Kadınlar Birliği’nde Suriyeli, Lübnanlı, Iraklı ve Mısırlı Müslüman kadınlar bir araya gelerek, kurucusu Mısırlı Huda Shaarawi'nin liderliğinde Filistinli Müslüman Kadınların davasını duyurmak için çalışmışlardır (A.g.e). Uluslararası konferanslar düzenleyerek kamuoyu yaratmaya gayret etmişler, Filistinli Müslüman kadınların bağımsızlık mücadelesine açıkça destek vermiş, oluşturdukları uluslararası dayanışma ağı ile sömürgeci devletlerin adaletsizliğine karşı 'Pan-Arap Feminizmi'ni ortaya atmışlardır.

Aynı dönemde Müslüman kadınların güçlendirilmesi ve toplumsal hayata katılımı için Aisha Abd al-Rahman ${ }^{4}$ gibi düşünürler Kur'ân-ı Kerim'i kendi zamanlarına uyarlamaya çalışmışlardır. Elbette Aisha Abd al-Rahman'dan önce, İslam'ın ilk günlerinde, Ummahat al-Mumininler yani "İnananların Anneleri"5, Kur'an-1 Kerim'in ${ }^{6}$ birçok sayfasının yorumlanmasına katkıda bulunmakla yetinmemiş, önemli hadis aktarıcıları (muhaddithâtlar) olarak İslam'a inkâr edilemez katkılar sunmuşlardır (Andújar, 2014: 176-177).

Bununla birlikte, 'İslâmî feminizm' teriminin en alışılagelmiş şekilde kullanılmaya başlanması 1990'lı yıllara denk gelmektedir. Örneğin Güney Afrikalı Müslüman feminist Shamima Shaikh; siyahî Afrika'yı ezen, yoksulluğa mahkum eden ve dinden döndüren sömürgeci ataerkil yapıya karşı, 1990'l1 y1llarda yapmış olduğu her konuşma ve makalede 'İslâmî feminizm' terimini sistematik olarak kullanarak hem kadını ikinci sınıf gören yapıya, hem de bir dini diğerinden 'geri' gören söyleme tavır almıştır. Suudi bilim kadını Mai Yamani, Güney Afrikalı Müslüman feminist Shamima Shaikh'ın izinden giderek; Feminizm ve İslam (1996) isimli kitabında 'İslâmî feminizm' konusunu aynı tavırla işlemiştir.

\footnotetext{
${ }^{3}$ Türk Kurtulus Savaşı'nda olduğu gibi.

${ }^{4}$ Yazarların notu: Bint al-Sati olarak da bilinir.

${ }^{5}$ Hz. Muhammet (s.a.v.)'in eşlerini tanımlayan unvan.

${ }^{6}$ Birçok tefsir $($ tafsîr $)$ kitabı Hz. Ayşe'nin tefsirinden pasajlar içermektedir. Kur'an'ın yorumlanmasında ayrıca Umm Salama'nın tefsiri de çok önemlidir.
} 


\section{V. İslam, Feminizm ve Yoksulluk Üzerine Sorular ve/veya Hipotezler}

İslâmî feminizmin ötekileştirme ve yoksulluk hakkında ortaya atmış olduğu tartışmaları kendi içinde sıralamak zordur. Yine de yoksullukla mücadele edebilmek için İslâmî feminizmin ortaya attığ 1 temel soruları şu şekilde sıralayabiliriz:

- Bugün var olan adaletsiz değerler sistemi, meşruiyetini nereden almaktadır?

- Toplumsal adaletsizlikle ve bunun doğal uzantısı olan yoksullukla mücadele edebilecek, güçsüzün hakkını güçlüden alabilecek, herkesin insanca yaşayabileceği değerler sistemini kurabilecek alternatif toplum düzeni nasıl oluşturulabilir?

- Sistemin doğrudan mağduru olan Müslüman kadınlara hangi rol düş̧ebilir?

- Elinde silahı olanların, ekonomik gücü bulunanların güçlerini korumak için kurdukları ve ezileni dışlayan, yoksulu daha da yoksullaştıran, sınırları daha da keskinleştiren bir yerleşik sistemle nas1l mücadele edilebilir?

- Avrupa'da veya Amerika'da 'göçmen kökenli' olanın, 'mülteci' olanın, veya 'Müslüman' olanın; 'saf kan' vatandaştan daha az değerli görüldüğü bir değerler sisteminde, her bir insanı eşit olarak merkeze alan adil bir düzen nasıl oluşturulabilir?

- 'Adalet' kavramını merkeze alan bir sistemi önerirken İslâmî feminizm, mevcut sistem içerisinde kalkınmadan ve yoksulluktan en çok etkilenen kadınlara, yoksullara, göçmenlere, ezilmişlere yol gösterebilecek bir yeni paradigmalar dizisiyle ne oranda/nasıl karşımıza çıkabilir ?

- Adaletsizliği ve ataerkil düzeni sorgulamak için Kur'an-Kerim, İslâmî feminizme nasıl rehberlik edebilir?

İnsanı -dinini, ırkını, sosyal sınıfını ayırt etmeksizin- merkezine alan İslâmî feminizmin sistemle ilgili bu sorunsallar dizisi; eşitlik ve adalet temelli yenilikçi post-modern ve post-kolonyal feminist teorilerin de belirgin bir örneği kabul edilmektedir. Ve feminizm üzerinde tartışırken, başlangıç noktası olarak, hegemonyacı Avrupa feminizminin kullanımdan düşürmüş olduğu dinî unsuru da inkâr etmemektedir.

Kur'an-1 Kerim'le ilgili feminist tefsir aslında, İslâmî feminizmin de ana ilham kaynağıdır (Mernissi, 2002). Bu tefsir; toplumsal eşitsizlik ve adaletsizlik ile mücadele edebilmek için kadınerkek ilişkilerini esas alan üç temel yaklaşımı benimsemiştir:

1 - Erkekler ile kadınlar arasındaki biyolojik farklılıkların yanında, kadınların herhangi bir ayrıma tabi tutulmamasını gösteren Kur'an-1 Kerim ayetleri nasıl incelenebilir?

2 - Genel olarak erkek üstünlüğünü meşrulaştıracak bir şekilde yorumlanmış olan, ama özünde eşitliğe yönelik olumlu unsurları vurgulayan ayetler nası1 yeniden öne çıkarılabilir?

3 - Çoğu inanan arasında yaygınlaşmış olan ve erkeklerin üstünlüğünü meşrulaştırmak için kullanılan Kur'an-1 Kerim ayetleri (Yaradılış hakkındaki ayetler gibi), yeniden okunarak nasıl revize edilebilir?

Andújar'a göre feminist tefsir, adil bir düzen arayışına tekabül etmektedir: "Aslında bu tür bir tefsir, birkaç on yıllık süredir diğer dinlerin de (Hıristiyanlık dâhil) yüzleşmekte olduğu teolojinin geniş bir feminist revizyonunun parçasıdır. Kendisine tarafsızlık süsü veren ve Kur'an-ı Kerim 'in mesajının salt aktarımı olarak yansitan ataerkil yorumlamaların, nasıl İslâm'ın özüne aykırı bir şekilde, ayrılıkçı söylemlerle koşullandırıldığını göstermektedir (2014: 180)".

İslâmî feminizm, Kur'an-1 Kerim'den yola çıkarak toplumsal adaletsizlik ve yoksulluk konusunu gündemine taşımıştır. Bu anlamda özellikle meşhur "Başlarına bir kadını geçiren bir kavim asla iflah olmaz" hadisini tartışmaya açmıştır. Fatima Mernissi (2002); Siyasi Harem isimli kitabında, 
İslâmî klasik metinlerin yeniden yorumlanarak, feminist bir gözden geçirme ile derinlemesine incelenmesi ve bilinmesi gerektiğini öne sürmektedir. Kadınların aleyhinde, ayrımcı yorum taşıyan hadisi reddetmektedir. Ancak Müslüman feminist Natalie Andújar'a göre, "bazı hadislerin radikal bir yöntemle bir köşeye ayrılması durumu, kaçınılmaz bir biçimde söz konusu hadislerin kadın-erkek ilişkilerinde toplumsal adaletsizliğe yol açan gerçekliği güçlendirerek, kadınlara yönelik ayrımcı söylemin derinleşmesine ve iyice yerleşmesine sebebiyet verecektir. Bu tutum; daha adil bir toplum inşası kaygısıyla hakça bir düzenin inşası için yola çıkan Müslüman feminist kadınların hadisi inkâr etmesi anlamina da gelecektir" (2014:181). Andújar'a göre İslâmî feminizm açısından amaç, "sadece belirli bir hadisin uydurulduğunu göstermekten ziyade, hadis derleyicileri tarafindan ortaya koyulan onaylama metodolojisinin problemli mahiyetini de göstermek" olmalıdır. Bir başka deyişle İslâmî feminizmin hedefi; belirli bir hadisin toplumsal adaletsizliğe sebebiyet verdiğini kanıtlamak değil, belirli bir dönemin düşünce yapısını yansıttıklarından dolayı hadislerin kural koyucu ve yasalar için temel teşkil edici niteliğinin olamayacağını göstermek olmalıdır.

$\mathrm{Bu}$ teorik tartışmalarda görüldüğ̈̈ üzere İslâmî feminizm, yoksulluk ve toplumsal adaletin tecellisi üzerine düşünürken, teolojiden çokça beslenmektedir.

\section{VII- Kadın ve Yoksulluk, Kisıtlama ve Sinırlamalar}

İslâmî feminizm düşüncesi, temelinde, ayrımcıllğa tabi tutulan ve bu yüzden eşitlikten, ve adaletten uzak kalan kadının toplumsal dışlanma deneyimlerini dikkate almayı talep etmektedir. Müslüman kadının toplumsal dışlanma deneyimini üç farklı yaklaşımla ele almaktadır:

1 - Geleneksel Reformcu Yaklaşım: Eşitlikçi ulema (dini bilim insanları) arasında en çok kabul gören yaklaşımdır. Geleneksel reformcular, kadınların ve erkeklerin manevi eşitliğini savunup onların rollerini, haklarını ve görevlerini hiyerarşik olarak değil, farklı ama eşdeğer olarak göz önünde bulundururlar. Kadınların toplumsal hayata kazandırılmasını ve yükümlülüklerinin hakça paylaşılmasını talep ederler. Geleneksel reformcular; dışlanmışlığa ve yoksulluğa sebebiyet verdiği gerekçesiyle, Batı toplumlarında yaşayan Müslüman kadınların herkes gibi aynı sosyal ve siyasal statüye sahip olabilmeleri gerektiğine inanırlar.

2 - Radikal Reformcu Yaklașım: Farklılaştırılmış sosyal rollere ve işlevlere dayandırılmadan, erkeklerin ve kadınların haklar temelindeki eşitliğini vurgulamak amacıyla, İslam'ın temel ilkelerine geri dönmeyi savunur. Geleneksel Müslümanlığ 1 ve toplumdaki adalet sistemini yeniden düzenleyebilmek için, İslâm'ın temel ilkeleri hakkında feminist bir düşünüş geliştirmenin gerekliliğine inanir.

3 - Liberal Reformcu Yaklassım: İslam'1 öznel olarak yasal ve resmi gereksinimlerin ötesinde, yaşanan ve formülleştirilen bir felsefe ve etik ilkeler bütünü olarak göz önünde bulundurur. Kur'an-1 Kerim'le ilgili feminist tefsir aslında, İslâmî feminizmin ana ilham kaynağıdır. Bu tefsir; toplumsal eşitsizlik ve adaletsizlik ile mücadele edebilmek için kadın-erkek ilişkilerini esas alan üç temel yaklaşımı benimsemiştir:

a - Erkekler ile kadınları arasındaki biyolojik farklılıklar yanında, kadınların herhangi bir ayrıma tabi tutulmamasını gösteren Kur'an-1 Kerim ayetlerinin incelenmesi;

b - Genel olarak erkek üstünlüğünü meşrulaştıracak bir şekilde yorumlanmış olan, ama özünde eşitliğe yönelik olumlu unsurları vurgulayan ayetlerin yeniden incelenmesi ve yeniden öne çıkarılması;

c - Çoğu inanan (mü'min) arasında yaygınlaşmış olan ve erkeklerin üstünlüğünü meşrulaştırmak için kullanılan ilgili Kur'an-1 Kerim ayetlerinin yeniden okunarak revize edilmesi (Yaradılış hakkındaki ayetler gibi).

Farklı İslâmî feminizmler; farklı söylemler taşımakla birlikte, tümü, kadınların birey olarak toplumsal hayata katılımının önemi ve kamusal alanın ayrılmaz bir parçası olmaları konusunda dînî 
önermeler getirir. Toplumsal huzurun ve adaletin tecellisi için, kadınların hakları için, çalışma ve mücadele etme amacını paylaşır. Aslına bakılırsa, İslâmî feminizmler yalnızca cinsiyet ilişkilerine değil, aynı zamanda en geniş anlamıyla ekonomik, dini çoğulculuk ve demokratik değerler esaslı sosyal alanda da uygulanması gereken temel bir Kur'an etiğine, yani adalet prensibine dayanır. $\mathrm{Bu}$ yüzden İslâmî feminizm; Müslüman kadınların hakları için mücadele ederken, aynı zamanda yoksulların, ötekileştirilen mazlumların, Avrupa ölçeğinde dışlanan göçmen ve mültecilerin de sözcüsü olmaya büyük bir anlam yükler. İslâmî feminizm bu açıdan evrensel amaçlara sahiptir.

\section{VII. İslâmî Feminizmin Yoksullukla Mücadele Yöntemleri}

Konumuz özelinde dışlanmışlığa ve yoksulluğa sebebiyet verdiği gerekçesiyle, Batı toplumlarında Müslüman kadınların mücadelesi dikkate alınmıştır.

Sosyal hareketlerin öncelikleri, elbette yer aldıkları bağlamlara göre farklılık arz etmektedir (Canatan, 2008). Ancak İspanya, Hollanda, Fransa veya Almanya'da, Müslüman feministlerin ortak bir talebi vardır: Hem siyasal, hem ekonomik, hem de sosyal alanlarda kadınlar; dinî kimlikleri yok sayılmadan, bu kimlikleri sebebiyle mağdur edilmeden, toplumsal yaşama eşit ve adil biçimde katılım hakkı talebinde bulunmaktadır.

Şüphesiz; kamusal alanda ötekileştirilen, ve bu ötekileştirme sonucunda yeri geldiğinde eğitim hakları ellerinden alınarak dışlanan Müslüman kadınların, uzun vadede daha vasıfsız işlerde çalışmaları veya iş piyasasından çekilmeleri sonucu yoksulluğa mahkum edilmeleri sebebiyle söyleyecek sözleri vardır...

Örneğin İslâmî feminizmi benimseyen Lyon Müslüman Kız Kardeşler Birliği (L'Union des soeurs musulmanes de Lyon), 'Fransız usulü' feminizmin laikçilik yapayım derken kendi içerisinde barındırdığı 1rkçılığa dikkatleri çekmiş; ve nesnellik kaygısı ile saf bir Batı karşıtlığı söylemi geliştirmemek adına Arap erkeklerinin cinsiyetçi toplumsal düzen oluşturma meyillerine karşı da eleştiri getirmişlerdir. 'İslâmî' feminizm, adalet duygusu ile öncelikle kendisine özeleştiri yapma cesaretini göstererek, güçlünün güçsüzü ezdiği her türlü 'örtük' sömürgeci düzeni sorgulamaya herkesi davet etmişlerdir. Bu yönüyle Fransız feminist Saïda Kada'nın 1995 yılında kurduğu Lyon Müslüman Kız Kardeşler Birliği, Cezayirli Houria Bouteldja tarafindan temsil edilen 'sömürge karşıtı feminizm'e de yaklaşmıştır (karşılaştırmalı bir okuma için Benelli ve diğerlerine bkz., 2006).

Dernek, Kur'an-1 Kerim metninin derin evrenselliğine girmeyi engelleyen geleneksel yorumlamayı ve o yorumlamalara ilişkin atomize yöntemleri mısra mısra ciddi biçimde eleştirmiştir. Hem Kur'an'la ilgili fikir ve ilkelere, hem de mevcut sosyal-ahlaki-ekonomik ve siyasal endişelere bir cevap ararken, aslında özellikle erkekler ve kadınlar arasındaki ilişkilere, ve bu ilişkilere dair bütünsel bir tefsiri gerçekleştirmek gerektiğini vurgulamıştır.

Lyon Müslüman Kız Kardeşler Birliği derneğinin bu duruşu, Batı Dünyası'nın öncü Müslüman feministlerinden Amina Wadud'un çağrısına verilen değerin tezahürüdür. Wadud (1999), Kur'an'ın erkekler ve kadınlar arasında ontolojik eşitliği kurduğunu iddia etmektedir ve Kur'an tefsirini, çerçevemesi gereken üç etik ve kozmolojik ilkenin geri kazanılmasına çağrıda bulunmaktadır: İslâmî feminizmin belkemiğini oluşturan birlik (tevhid), adalet ( $a d l$ ) ve Allah bilinci (takva).

Wadud, birliğin her türlü ikiliğe üstün geldiği İslâmî değerler dizisinin özünde olan eşitliği gerçekleştirmek adına, tüm Müslümanları kendi toplumlarında reform yapmaya ve öncelikle yoksulluğu ortadan kaldırmaya davet etmektedir.

Müslüman kadınların mağduriyetine karşı Avrupa'da laikçi Devlet'in kalesi olan Fransa'da 'İslam'a Dönenler'in eylemleri, bu anlamda önemlidir. Söz konusu eylemler, Fransız Müslüman feminist Saïda Kada'nın 1995 yılında Lyon Müslüman Kız Kardeşler Birliği'ni kurması ile başlamıştır. Kendi dindaş kız kardeşleri ile birlikte, 'Fransız usulü' feminizmin (féminisme à la française) kendi 
gibi olmayan kadınlar adına konuşma ve yargıları keskinleştirme konusunda hem cinslerine karşı yargıları ve söylemleri daha da derinleştirerek, var olan ataerkil sistemin yanında, yeni engeller oluşturduklarını açıklamıştır.

Örneğin 'hegemonik feminizm', özellikle 1980'li y1lların sonundan itibaren, Müslüman çoğunluklu ülkelerden gelen yabancı işçilerin yerleşmesiyle kendini hissettirmiştir. $\mathrm{Bu}$ sebeple Fransa'da İslâmî feministlerin zorlu görevlerinden biri de, okullarda türban ve kamusal alanlarda burka/peçe kullanımları etrafındaki ihtilafla ilgili olmuştur. Bu dönemde kamusal alanlardaki başörtüsü kullanımına karşı olan Fransız laikçi feministlerle tartışan Zahra Ali gibi Müslüman feministler, bu gibi söylemlerin/pozisyonların tek bir etnomerkezci fikre dayalı olduğunu ve kendinden farklı olan kadını daha da dışlamak ve yoksullaştırmaktan başka bir işe yaramayacağını öne sürmüştür. Ona göre "Bizim feminizm modelimiz tüm kadınlar için en iyisidir diyen tahakkümcü bir yaklaşım, ezileni daha da ezen bir yaklaşımdan başka bir şey değildir" (2012).

Zahra Ali, laik feminist modelin yegâne model olmadığını savunmuştur. Dikkati birçok Müslüman kadına yapılan ayrımın arkasındaki sosyal ve ekonomik eşitsizlikler gibi daha hayati ve önemli sorunlara çevirerek, Fransız laikçi feminist söylemin 'türban' gibi konular üzerine odaklanarak esas meseleyi gözden kaçırdığını açıkça ifade etmiştir.

Zahra Ali (A.g.e.) ayrıca, Müslüman kadınları toplumda mevcut olan karar merciilerine ve kamusal alandaki tüm mekanizmalara dahil olmaları noktasında teşvik ederken; erkekleri de İslâmî feminist harekete dâhil etmenin önemini vurgulamıştır. Bu anlamda İslâmî feminizmin esas meselesi kadınları erkeklerden üstün görmek değildir. Aksine, İslâmî feminizm, adil bir toplumun inşası için, "cinsiyet adaletini merkezine alan, tek tip kadın anlayışına karşın farklılıkların hem kadınları, hem de demokrasiyi zenginleştirdiğine inanan; kadın ve erkeğin toplumsal hayatta sunulan haklara, firsatlara ve olanaklara eşit oranda sahip olmasl gerektiğini savunan; demokratik mekanizmaları kullanarak kadının siyasal, sosyal ve ekonomik alanda temsil oranını arttırmayı hedefleyen bir sivil toplum hareketi" olarak meşruiyetini ve toplumsal hayattaki önemini vurgulamaktadır.

\section{Bir Sonuç}

VIII- Yoksullukla Mücadelede İslâmî Feminist Düşünce ve Harketlerin Önemi Üzerine

Bugün gelinen noktada dünyada adaletsiz bir düzenin hüküm sürdüğ̈ bilinmektedir. $\mathrm{Bu}$ adaletsiz sistemde giderek derinleşen yoksullukta ise, Avrupa özelindeki ekonomik krizden en çok etkilenenler arasında göçmen kökenli Müslüman kadınların olduğu aşikârdır. Ancak birçok tarihçinin ve antropoloğun kanıtladığı gibi adaletsizliğe mahkumiyet, bir kader değildir. Müslüman kadınlar; sömürge dönemini yaşamış tarihsel 'mağdurlar' olarak, direnç stratejileri oluşturmak ve içinde yaşadıkları eşitsizlik durumunu değiştirebilecek eylem gücüne sahiptir. Bu stratejiler içerisinde Avrupa'da 'ötekileştirilmiş' Müslüman kadınlarının kendi inançları, söylemleri, kategorileri ve mantıklarıyla 'eşit hemcins' olarak, Avrupalı Feminist hareketin içerisinde kendilerini temsil etme ve söz söyleyebilme talepleri önemlidir.

Avrupa feminizmi açısından, Avrupa toprakları içerisinde yaşayan farklı kimlikteki kadınların gerçekliğini dikkate alan; 'uçlardan gelen', 'beyaz olmayan', 'Hıristyan olmayan' gibi... farklı feminizmleri anlamak ve onları da dahil eden daha evrensel, hümanist ve kapsayıcı bir feminist pozisyonu yakalamak ve geliştirmek, Avrupa Feminizmi'nin meşruiyeti açısından kaçınılmazdır.

İslâmî feminizmin de 3. Dalga Feminist hareketler içerisindeki diğer feminist hareketler gibi dikkate alınarak feminist hareketin geliştirilmesi, kıymetli bir kazanımdır. Adil bir toplumun inşası için, din veya ırk gibi doğuştan gelen özellikleri sebebiyle kadınların birbirini tecrit etmemesi, dinin veya ırkın bir ayrım unsuru olarak agılanmasının ortadan kaldırılması önemlidir. 
İnsanları kategorilerle ayırıp bölmek yerine, adaletin herkes için tecellisini esas alan bir feminist anlayışta birleşmek, kadın-erkek arasındaki dengesiz toplumsal ilişkileri kırmakla kalmayıp; dil, din, ırk, sınıf farketmeksizin yoksulluğa ${ }^{7}$ odaklanmayı da sağlamaktadır.

Bu bağlamda bu çalışma, İslâmî feminizmin yoksullukla ilgili geliştirmiş olduğu yaklaşımları ana hatları ile aktarmayı amaçlamıştır. Yoksullukla mücadelede ırkçı ve cinsiyetçi algılamaların kırılmasının önemine değinmiştir. Baskın feminizmin bilhassa, Avrupa'da kaç Müslüman kadının derdine hitap ettiği, kaç Müslüman kadının gündelik hayattaki belirli problemlerine ve taleplerinine cevap verdiği gibi sorgulamalarla, daha kapsayıcı bir feminizmin gerekliliğini anlatmak istemiştir.

\section{KAYNAKÇA}

Ali, Z. (Ed.). (2012). Féminismes islamiques. Paris: La fabrique éditions.

Andújar, N. (2014). "Feminismos islámicos: entre debates teológicos y movimientos sociales", in Tamayo, J. J. (ed.), Islam: Sociedad, Política y Feminismo, Madrid: Dickinson.

Badran, M. (2009). Feminism in Islam: secular and religious convergences. Oxford: Oneworld Publications.

Benelly, N. et al. (2006). "Sexisme et racisme: le cas français", Nouvelles Questions Féministes, vol. $25, \mathrm{n}^{\mathrm{o}} 1$.

Berthier, R. (2009). Un voile sur la cause des femmes. Paris: Éd. du Monde libertaire.

Bouzar, D., \& Kada, S. (2003). L'une voilée, l'autre pas. Paris: Albin Michel.

Canatan, K. (2008). "Hollanda Toplumunda Yabancı Karşıtı Tutumların Analizi", Turkish Studies, vol. $3 / 7,220-240$.

Chakrabarti, S., \& Chakravorty, S. (2011). The impact of the postcolonial theories of Edward Said, Gayatri Spivak, and Homi Bhabha on western thought: the third-world intellectual in the firstworld academy. Lewiston: Edwin Mellen Press.

Collins, P. H. (2009). Black feminist thought: knowledge, consciousness, and the politics of empowerment. New York: Routledge.

Dilli, S. (2010). Les médias des 'groupes ethniquement minorisés » en France et en Turquie : Étude comparée sur la représentativité et la citoyenneté. Paris: Sorbonne Üniversitesi / İstanbul: Bilgi Üniversitesi. Doktora Tezi, $510 \mathrm{~s}$.

Demir, H. (2013). "Fatma Aliye Hanım'ın Çerçevesinden Kadın Haklarının Sınırları", Turkish Studies, vol. 8/6, 1059-1068.

Geerts, N., Javeau, C., Fourest, C., \& Sondron, J. (2010). Fichu voile !: petit argumentaire laïque, féministe et antiraciste. Bruxelles: L. Pire.

Howard, J. A., \& Allen, C. (Eds.). (2000). Feminisms at a millennium. Chicago: University of Chicago Press Journals.

\footnotetext{
${ }^{7}$ Yoksulluk, dar anlamıyla "insanın fiziksel ihtiyaçlarını yeterince karşılayabileceği maddi kaynaklardan yoksun olması" olarak tanımlanmıştır. Bu tanım yakın geçmişe kadar yoksulluk çalışmalarına yön vermişken, özellikle II. Dünya Savaşı sonrası ortaya çıkan yeni yaklaşımla, yoksulluğun yalnızca maddi kaynakların yetersizliği ile sınırlı kalmadı̆̆ı, insanın kapasitesini kullanıp geliştirebileceği sosyal kaynaklardan mahrum olmasının da bir yoksulluk yarattığı yönündeki görüş güçlenmiştir.
} 
Köroğlu, C.Z. (2013). "Modern Kamusal Alana Eleştirel Yaklaşımlar: Genel Bir Değerlendirme (Postmodernizm, Feminizm ve Din)", Turkish Studies, vol. 8/6, 431-457.

Latte Abdallah, S. (Ed.). (2010). Critique international. Le féminisme islamique aujourd'hui. Paris: Presses de Sciences Po.

Latte Abdallah, S. (Ed.). (2011). Revue du monde musulman et de la Méditerranée. Féminismes islamiques. Aix-en-Provence: Publications de l'Université de Provence.

Mahmood, S. (2005). Politics of piety: the Islamic revival and the feminist subject. Princeton (N.J.): Princeton University Press.

Marcotte, R. D. (2010). Un islam, des islams? Paris: L'Harmattan.

Martín Muñoz, G. (2005). "Mujeres musulmanas: entre el mito y la realidad", in F. Checa y Olmos (ed.), Mujeres en el camino: el fenómeno de la migración femenina en España, Barcelona: Icaria.

Mernissi, F. (2002). El harén político: el Profeta y las mujeres, Oriente y Mediterráneo.

Mir Husseini, Z. (2010). "Tradición jurídica islámica y feminismo: un nuevo diálogo", IV Congreso Internacional de Feminismo Islámico, Madrid.

Moghadam, V. M. (Ed.). (2007). From patriarchy to empowerment: women's participation, movements, and rights in the Middle East, North Africa, and South Asia. Syracuse (N.Y.): Syracuse University Press.

Moghissi, H. (1999). Feminism and Islamic fundamentalism: the limits of postmodern analysis. New York: Zed Books.

Mohanty, C. T., Russo, A., \& Torres, L. (Eds.). (1991). Third World women and the politics of feminism. Bloomington: Indiana University Press.

Navarro, L. (2008). Contra el Islam. La visión deformada del mundo árabe en Occidente. Córdoba: Almuzara.

Nash, M. et al. (2013). Desvelando la historia. Fuentes históricas coloniales y postcoloniales en clave de género. Granada: Comares.

Nash, M. (2004). Mujeres en el mundo. Historia, retos y movimientos. Barcelona: Alianza editorial.

Rhouni, R. (2010). Secular and Islamic feminist critiques in the work of Fatima Mernissi. Leiden: Brill.

Safi, O., \& Hammer, J. (Eds.). (2013). The Cambridge companion to American Islam. Cambridge: Cambridge University Press.

Said, E. W., \& Barsamian, D. (2003). Culture and resistance: conversations with Edward W. Said. London: Pluto.

Saikia, Y., \& Haines, C. (Eds.). (2015). Women and peace in the Islamic world: gender, agency and influence. London: I.B.Tauris \& Co Ltd.

Sikri, R. (1999). Women in Islamic culture and society: a study of family, feminism and franchise. New Delhi: Kanishka Publishers Distributors.

Suzack, C. (Ed.). (2010). Indigenous women and feminism: politics, activism, culture. Vancouver: UBC Press.

Tucker, J. E. (Ed.). (1993). Arab women: old boundaries, new frontiers. Bloomington: Indiana University Press. 
Wadud, A. (1999). Qur'an and Woman. Rereading the Sacred Text From a Woman's Perspective. Oxford: Oxford University Press.

Yamani, M., \& Allen, A. (Eds.). (1996). Feminism and Islam: legal and literary perspectives. Berkshire: Published for Centre of Islamic and Middle Eastern Law, School of Oriental and African Studies, University of London, Ithaca Press. 